\title{
Hygiene Awareness among Public University Students in Malaysia during COVID-19 Outbreak
}

\author{
Nor Hazlyna, $\mathbf{H}^{1}$, Rafidah Abd Razak², M.G.Hassan³ ${ }^{3}$ Amiera Syazlin Md Azhar ${ }^{4}$, \\ Maizatul Fatihah Mohd Salleh ${ }^{5}$, Jegatheeswaran Kesavan ${ }^{6}$, Muhammad Ihsan Akif Anuar ${ }^{7}$, Ooi Gi Yuen \\ ${ }^{1,2,4,5,7,8}$ School of Computing, Universiti Utara Malaysia, 06010 Sintok, Kedah, Malaysia \\ ${ }^{3}$ School of Technology Management \& Logistic, Universiti Utara Malaysia, 06010 Sintok, Kedah, Malaysia \\ ${ }^{6}$ School of Multimedia Technology \& Communication, Universiti Utara Malaysia, 06010 Sintok, \\ Kedah, Malaysia \\ hazlyna@soc.uum.edu.my ${ }^{1}$
}

Article History: Received: 10 November 2020; Revised: 12 January 2021; Accepted: 27 January 2021; Published online: 05 April 2021

Abstract: The origin of COVID-19 was found in December 2019 from Wuhan, Hubei Province, China; and it has spread very fast all around the world. It is a worrying disease as many positive cases are reported increasing day by day. The emerging of COVID-19 outbreak requires social distance and other interventions to protect human and environmental health. The objective of this study is to promote awareness among public university students on the importance of hygiene during the pandemic of COVID-19. Therefore, a study was carried out to assess the hygiene awareness among public university students during this outbreak. A cross-sectional study was conducted using an online survey method among public university students. The study generally is aimed to determine COVID-19 awareness, attitudes, knowledge, and related behaviours among the students. The results show that most of the students are aware of the current issues of COVID-19, and at the same time they practice good self-hygiene to prevent themselves from getting infected. However, there is still room for the university students to improve their hygiene awareness, and exercising more complete precautionary matters to prevent the spread of COVID-19.

Keywords: COVID-19, hygiene, face mask, hand sanitizer, public university

\section{Introduction}

Coronavirus is a virus that can cause several symptoms like coughing, sneezing, fever, breathing trouble, and lung infection. The World Health Organization (WHO) declared that Coronavirus Disease 19 (COVID-19) is the official name for the 2019 novel coronavirus (Adhikari et al., 2020). This new disease was unknown before December 2019, and was identified as pneumonia when it emerged in Wuhan, China. The disease has spread all over the world and Malaysia is also affected by the disease. In Malaysia, there was a case of COVID-19 detected on 24 January 2020 which later becomes the start of the pandemic (World Health Organization, 2020). In an effort to curb the spread of COVID-19, every country should put an effort to decrease the risk of getting infected. A proper hand hygiene has proven to be a useful method to control many infectious diseases (Or, Wong, \& Chung, 2020).

Hygiene is generally defined as a branch of science engaged in knowledge and practices relating to health promotion (Sarfaraz et al., 2015). The spread of this recent disease could be prevented by following hygiene practices. The COVID-19 virus mainly spreads by saliva droplets or nose discharge whenever an infected person coughs or sometimes sneezes (World Health Organization, 2020). Currently, the vaccines and treatment of COVID-19 has yet to be found. Hygiene awareness is essential to restrain the spread of this infection. The virus may cause people to suffer, generally with a mild to severe acute respiratory tract disease which is similar to a common cold. Some symptoms of a person infected with COVID-19 disease include coughing, aches, fever, runny nose, and pains. For those with a weak immune system, the elderly and the very young, there is a risk that the virus might cause a lower respiratory tract illness, like pneumonia or bronchitis, and much more severe.

There are several ways to prevent the spread of COVID-19 by washing the hands with an alcohol-based hand rub frequently and thoroughly or washing them with soap and water. This is because alcohol-based hand rub and soap with water can minimize the risk of contracting the virus. Another way is by wearing a face mask. It is advised to wear a face mask when venturing outdoors or in areas where distance from other people is difficult to maintain (LiveScience, 2020). This could reduce the viral spread among people.

While the immediate risk of this new virus to the Malaysian public is believed to be moderate at this time, this study main objective is to promote awareness among public university students on the importance of hygiene during the pandemic of COVID-19. The study generally is aimed to determine COVID-19 awareness, attitudes, knowledge, and related behaviours among the students. The study is conducted among university students 
to encourage them to practice good self-hygiene during COVID-19 pandemic as their part of taking everyday preventive actions as a basic step to respond to this emerging public health threat.

\section{Background}

\subsection{Literature Review}

A patient in the town of Wuhan, China was diagnosed with acute pneumonia in early December 2019. The World Health Organization (WHO) regional office in Beijing had received notification from the same town about the cluster of patients with unexplained cause of pneumonia. Wuhan is the capital city of Hubei Province in Central China. With a population of 11 million people, it is known as the seventh largest city. Wuhan Institute of Virology's Researchers carried out metagenomics analysis by using next-generation sequencing sample obtained from bronchoalveolar lavage over the next few days and defining a novel coronavirus as the possible ethology. Soon they announced that it was named as novel coronavirus (nCoV-2019), while it was refer as 2019 novel coronavirus (2019-nCoV) by The United States Centers for Disease Control and Prevention (CDC).

As of February 11, 2020, there are 43103 cases of 2019-nCov reported in the last 24 hours. $98.9 \%$ of the cases are happened in China which leads to 1017 deaths. As the cases evolving, accurate up-to-date information on the number of cases and the recommendation on how to manage the case could be found online because of the rapid change of the situations. As in January 2020, the number of infections outside of China remains small (approximately 395), and the total death at only 1 (in the Philippines), but cases have been detected in 24 countries, including 18 cases in Malaysia. The most common COVID-19 symptoms are fever, sore throat, dry cough, diarrhoea, pain and aches. Usually, the symptoms are mild at first and started to get worse gradually. However, there are also cases where they are infected but did not develop any symptoms. About $80 \%$ of people infected recover without any special treatment and around one out of six people who were infected becomes develop difficulty in breathing which leads to serious illness. Older individuals, including those with underlying medical conditions such as high blood pressure, heart attacks or diabetes, are more likely to develop chronic disease. $2 \%$ of people with the disease mentioned have died. It is advisable for people with difficulty breathing and cough to seek medical attention as soon as possible.

More evidence have showed the connection between the 2019-nCoV-Sub-Species of the Rhinolophus bat and the related identified sub-species of the Coronavirus $(\mathrm{CoV})$. These subspecies are rich and present throughout Southern China, Asia, the Middle East, Africa, and Europe. Recent studies show that over $500 \mathrm{CoV}$ s in Chinese bats have been identified (World Health Organization, Novel Coronavirus (2019-nCoV) Situation Report, 2020). In 2018, one case of the disease named as Middle East Respiratory Syndrome Coronavirus (MERS-CoV) was reported by Malaysia's IHR National Focal Point. A 55-year old man living in Malaysia who visited Kingdom of Saudi Arabia from 13 to 23 December 2017 as a member of a pilgrimage group recorded had direct contact with a camel and drinking unpasteurized camel milk while visiting a camel farm in Riyadh. He developed the symptoms on 24 December after return back to Malaysia. He was treated and hospitalized in Malaysia (World Health Organization, Middle East respiratory syndrome coronavirus (MERS-CoV) - Malaysia, 2018).

COVID-19 could be the second pandemic of the 21st century after the pandemic of influenza A H1N1 in the year 2009. As a result of the increasingly galloping epidemic of globalization and international travel, on 11 March 2020, the World Health Organization (WHO) then declared COVID-19 as a pandemic, two days after the first official confirmation of community-acquired pneumonia clusters in Wuhan, China's Hubei Province, on 31 December 2019 (Day 1). Almost 80,000 deaths has been reported in more than 1.35 million people worldwide on the 100 Day, 8 April 2020. As a precaution, proactive steps to control infections in hospitals has been implemented. In addition, non-pharmaceutical public health initiatives also has been implemented. The initiatives includes border protection or closure, checking of all incoming travellers or returnees. They need to undergo 14 days quarantine first before return to their home. Besides, hand hygiene and social distancing including school closure and cancelled of mass gatherings and the termination of all socio-economic activities, with the exception of essential services, were also implemented in order to minimize the risk of population transmission It is believed that continued good personal hygiene and community-wide masking can break the COVID-19 transmission chain by reducing the risk of infection at the same time provide protection to those who are not infected so that COVID-19 cases could be controlled and cease soon.

According to Dalton, Corbett and Katelaris (2020), it is estimated that around two-thirds of COVID-19 cases exported from China were undetected globally between 1 and 13 January 2020. Scientists immediately began investigating the origins of the new coronavirus, and on 10 January 2020, the study team led by Prof. Yong-Zhen Zhang published the first genome of COVID-19. This virus spread rapidly in just one month all over China dur- 
ing the Chinese New Year, when it is the time where most of the Chinese people have a high level of human mobility (Adhikari et al, 2020). It is believed that early patients reported some connection to the Huanan Seafood Market located Wuhan, China, showing that these early infections were caused by the spread from animal to human. It becomes pandemic all over the world due to the high and fast human-to-human transmission of the virus (Chen et al., 2020). More than 24550 cases of COVID-19 were confirmed as of February 5, 2020. It includes more than 190 cases outside China, and more than 490 reported deaths worldwide (Hellewell et al., 2020). Studies have indicated suggested that the virus spread rapidly and has been spreading in many countries since the outbreak in China (Adhikari et al., 2020). Both the pharmaceutical and non-pharmaceutical steps against COVID-19 are eligible. Non-pharmaceutical interventions such as face mask wearing, and hand washing are necessary to reduce the risk (Chen et al, 2020). Droplets transmission which happened when the person infected coughs or sneezes are one the ways of the virus transmission. Besides, contact transmission which happened when the infected person touches a surface or object which causes the object contaminated with the virus and the other person who were not infected touch it and subsequently touch their mouth, nose, or eyes. The third way of transmission is aerosol transmission which is when respiratory droplets mix in the air and form aerosols and can cause infection when large doses of aerosols are inhaled into the lungs in a relatively closed atmosphere) (Adhikari et al. 2020).

A proper hand washing is recognized today as a way to prevent infection and disease transmission. The hands are a convenient way to spread several diseases and illnesses. Bacteria and other pathogens can be transferred from non-living objects into hands and then indirectly spread from one person to another. Continuing that trend leads to widespread illness. As a result, proper soap and water hand washing will help eliminate certain bacteria from the skin (Mohammadi, Dalvandi, \& Chakeri, 2020). Previous study shows that the performance of hand hygiene among students are proper and reasonable. A research by Mohammadi, Dalvandi and Chakeri (2020) shows that the attitude of students towards hand-washing improved as a result of education and that the intervention group was more optimistic towards hygiene and hand-washing than the control group. (Mohammadi, Dalvandi, \& Chakeri, 2020). Another study by Agarwal et al. (2020) shows that the practice of hand hygiene among students is good, and they were aware of their hygiene (Agarwal et al., 2020). Based on another research made by Sarfaraz et al. (2015), their result show that most of the population are aware of their hand hygiene with the total of 188 people are aware of the hand hygiene, while another 12 people state otherwise (Sarfaraz et al., 2015).

To conclude, the new COVID-19 outbreak information available on the WHO website and through national and local public health authorities should be made known to all as it is important in order to keep up to date with the latest information.

\section{Method}

\subsection{Participants}

Public university students were chosen as the respondents of this research. A total of 200 students participated in answering the questionnaire to acquire more information about how they take care of their personal hygiene during the COVID-19 pandemic. The students were chosen randomly by blasting the online survey through WhatsApp Messenger.

\subsection{Method/Procedure}

\subsubsection{Questionnaire}

A custom Google Forms questionnaire was developed and distributed online for data collection. The questionnaire was divided into four sections that consists of demographic and background information, self-hygiene information, surroundings information and self-knowledge information. Demographic and background information section were based on standard categories which are multiple choices, same goes to self-hygiene information section, while surroundings information section and self-knowledge information based on the level of satisfaction was followed by level of agreement on 5-point Likert Scale.

\subsubsection{Data Collection}

Responses were collected in a range of 150 to 200. Links to the survey were distributed by using social networking application, WhatsApp messenger from $8^{\text {th }}$ of May 2020 until $22^{\text {nd }}$ of May 2020. The answers to the questionnaire collected were fully anonymous responses. 


\subsubsection{Data Analysis}

The questionnaire was created by using Google Forms and was automatically analyzed. The raw data could also be accessed directly to see one-by-one responses. In order to store and organize the results, Google Sheets with each row features the responses from each respondent and each column features a question from the questionnaire. All data were analyzed and discussed by sections:

i. Demo-graphic and Background Information

ii. Self-Hygiene Information

iii. Surroundings Information

iv. Self-Knowledge Information

\section{Result}

\subsection{Demo-graphic and Background Information}

A total of 200 public university students participated in this study. The survey was conducted from $8^{\text {th }}$ of May 2020 until 22 $2^{\text {nd }}$ of May 2020. As a result, one hundred and six (53\%) respondents are female and 94 (47\%) respondents are male. Most of the respondents are in their sixth semester (36\%) while the second highest are from their fourth semester (35\%). Most of the respondents are from public universities in north of Malaysia. Most of the respondents are undergraduates' students which is about $98 \%$ and another $2 \%$ are postgraduate students.

Table Error! No sequence specified.. Demography and Background Information

\begin{tabular}{|c|c|c|c|}
\hline Category & Group & Total & Percentage (\%) \\
\hline Age & $\begin{array}{l}18-21 \\
22-25 \\
26-29 \\
>30\end{array}$ & $\begin{array}{l}45 \\
152 \\
3 \\
0\end{array}$ & $\begin{array}{l}22.5 \\
76 \\
1.5 \\
0\end{array}$ \\
\hline Gender & $\begin{array}{l}\text { Male } \\
\text { Female }\end{array}$ & $\begin{array}{l}94 \\
106\end{array}$ & $\begin{array}{l}47 \\
53\end{array}$ \\
\hline Semester & $\begin{array}{l}\text { Semester } 1 \\
\text { Semester } 2 \\
\text { Semester } 3 \\
\text { Semester } 4 \\
\text { Semester } 5 \\
\text { Semester } 6 \\
\text { Semester } 7 \\
\text { Semester } 8 \\
\text { Foundation }\end{array}$ & $\begin{array}{l}5 \\
30 \\
12 \\
70 \\
7 \\
72 \\
1 \\
2 \\
1\end{array}$ & $\begin{array}{l}2.5 \\
12 \\
6 \\
35 \\
3.5 \\
36 \\
0.5 \\
1 \\
0.5\end{array}$ \\
\hline Education Level & $\begin{array}{l}\text { Undergraduates } \\
\text { Postgraduates }\end{array}$ & $\begin{array}{l}196 \\
4\end{array}$ & $\begin{array}{l}98 \\
2\end{array}$ \\
\hline
\end{tabular}

\subsection{Self-Hygiene Information}

In general, most respondents have good self-hygiene as indicated in the survey. Majority of the respondents have conducted a proper self-hygiene. Table 2 discusses on self-hygiene information. From the table, $63.5 \%$ of the respondents have hand sanitizer when they are in the university. Among them $30 \%$ of the respondents often bring hand sanitizer whenever they are in the university, while $48 \%$ often use hand sanitizer every time they interact with anything. Meanwhile, $82 \%$ of the respondents use soap every day in their daily life, showing that most of them practice good hygiene. Even though a total of $69.5 \%$ of the respondents do not bring soap every- 
where they go in the university, they often use soap provided in many public places in the university. Furthermore, $71.5 \%$ of the respondents wash their hands after coming back to their student residential hall and $93 \%$ said 'yes' to washing their hands before meals in any cafe in the university. The findings also indicated that $99 \%$ of the students wash their hands after using the washroom in the university. Moreover, $43 \%$ of them always wash their hands after using public transport within the university, $30.5 \%$ after contact with a person and $82.5 \%$ after contact with animals. Majority of the respondents with $74 \%$ use a face mask. Among them, $36.5 \%$ of them use it in the university, thus, this could be indicated that they are aware of the situation happening outside the university. Thus, $87 \%$ of the respondents said 'yes' in using a face mask outside of the university. From the above statistics, it is concluded that most of the students in the university partake in good self-hygiene practice.

Table 2. Self-Hygiene Information

\begin{tabular}{|c|c|c|c|}
\hline Questions & Group & Total & $\begin{array}{l}\text { Percentage } \\
(\%)\end{array}$ \\
\hline $\begin{array}{l}\text { Do you have hand sanitizer with } \\
\text { you? }\end{array}$ & $\begin{array}{l}\text { Yes } \\
\text { No }\end{array}$ & $\begin{array}{l}127 \\
73\end{array}$ & $\begin{array}{l}63.5 \\
36.5\end{array}$ \\
\hline $\begin{array}{l}\text { Do you bring hand sanitizer eve- } \\
\text { rywhere you go out? }\end{array}$ & $\begin{array}{l}\text { Yes } \\
\text { Sometimes } \\
\text { No }\end{array}$ & $\begin{array}{l}60 \\
70 \\
70\end{array}$ & $\begin{array}{l}30 \\
35 \\
35\end{array}$ \\
\hline $\begin{array}{l}\text { How often do you use hand sani- } \\
\text { tizer at outside? }\end{array}$ & $\begin{array}{l}\text { Sometimes } \\
\text { Every time I interact with anything } \\
\text { I did not use hand sanitizer at all }\end{array}$ & $\begin{array}{l}93 \\
48 \\
59\end{array}$ & $\begin{array}{l}46.5 \\
48 \\
59\end{array}$ \\
\hline $\begin{array}{l}\text { Do you bring soap everywhere } \\
\text { you go? }\end{array}$ & $\begin{array}{l}\text { Yes } \\
\text { Sometimes } \\
\text { No }\end{array}$ & $\begin{array}{l}17 \\
44 \\
139\end{array}$ & $\begin{array}{l}8.5 \\
22 \\
69.5\end{array}$ \\
\hline $\begin{array}{l}\text { How often do you wash your } \\
\text { hands when you are in outside? }\end{array}$ & $\begin{array}{l}\text { Everyday } \\
\text { Sometimes } \\
\text { I rarely wash my hands } \\
\text { I never wash my hands at all }\end{array}$ & $\begin{array}{l}164 \\
31 \\
5 \\
0\end{array}$ & $\begin{array}{l}82 \\
15.5 \\
5 \\
0\end{array}$ \\
\hline $\begin{array}{l}\text { Do you wash your hands after } \\
\text { coming back to student residential } \\
\text { hall? }\end{array}$ & $\begin{array}{l}\text { Yes } \\
\text { Maybe } \\
\text { No }\end{array}$ & $\begin{array}{l}143 \\
40 \\
17\end{array}$ & $\begin{array}{l}71.5 \\
20 \\
8.5\end{array}$ \\
\hline
\end{tabular}

\begin{tabular}{|c|c|c|c|}
\hline $\begin{array}{l}\text { Do you wash your hands before } \\
\text { meals in any cafe? }\end{array}$ & $\begin{array}{l}\text { Yes } \\
\text { Maybe } \\
\text { No }\end{array}$ & $\begin{array}{l}186 \\
13 \\
1\end{array}$ & $\begin{array}{l}93 \\
13 \\
0.5\end{array}$ \\
\hline $\begin{array}{l}\text { Do you wash your hands after } \\
\text { using the public toilet? }\end{array}$ & $\begin{array}{l}\text { Yes } \\
\text { Maybe } \\
\text { No }\end{array}$ & $\begin{array}{l}198 \\
2 \\
0\end{array}$ & $\begin{array}{l}99 \\
2 \\
0\end{array}$ \\
\hline $\begin{array}{l}\text { Do you wash your hands after } \\
\text { using public transport? }\end{array}$ & $\begin{array}{l}\text { Yes } \\
\text { Maybe }\end{array}$ & $\begin{array}{l}86 \\
55 \\
59 \\
\end{array}$ & $\begin{array}{l}43 \\
27.5\end{array}$ \\
\hline
\end{tabular}


Nor Hazlyna, H, Rafidah Abd Razak, M.G.Hassan, Amiera Syazlin Md Azhar, Maizatul Fatihah Mohd Salleh, Jegatheeswaran Kesavan, Muhammad Ihsan Akif Anuar, Ooi Gi Yuen

No 29.5

\begin{tabular}{|c|c|c|c|}
\hline $\begin{array}{l}\text { Do you wash your hands after } \\
\text { contact with a person when you } \\
\text { are in outside? }\end{array}$ & $\begin{array}{l}\text { Yes } \\
\text { Maybe } \\
\text { No }\end{array}$ & $\begin{array}{l}61 \\
66 \\
73\end{array}$ & $\begin{array}{l}30.5 \\
33 \\
36.5\end{array}$ \\
\hline $\begin{array}{l}\text { Do you wash your hands after } \\
\text { contact with animals when you } \\
\text { are in outside? }\end{array}$ & $\begin{array}{l}\text { Yes } \\
\text { Maybe } \\
\text { No }\end{array}$ & $\begin{array}{l}165 \\
18 \\
17\end{array}$ & $\begin{array}{l}82.5 \\
9 \\
8.5\end{array}$ \\
\hline $\begin{array}{l}\text { Do you have face mask when you } \\
\text { are outside? }\end{array}$ & $\begin{array}{l}\text { Yes } \\
\text { No }\end{array}$ & $\begin{array}{l}148 \\
52\end{array}$ & $\begin{array}{l}74 \\
26\end{array}$ \\
\hline $\begin{array}{l}\text { Do you use face mask in public } \\
\text { places? }\end{array}$ & $\begin{array}{l}\text { Yes } \\
\text { Sometimes } \\
\text { Never }\end{array}$ & $\begin{array}{l}73 \\
75 \\
52\end{array}$ & $\begin{array}{l}36.5 \\
37.5 \\
26\end{array}$ \\
\hline $\begin{array}{l}\text { Do you use face mask outside of } \\
\text { public places? }\end{array}$ & $\begin{array}{l}\text { Yes } \\
\text { No }\end{array}$ & $\begin{array}{l}174 \\
26\end{array}$ & $\begin{array}{l}87 \\
13\end{array}$ \\
\hline
\end{tabular}

\subsection{Surroundings Information}

Based on the Surroundings Information Survey, the findings indicate that the students are aware of the disease because most of them have a good Surrounding Information. Table 3 shows that most of the respondents mentioned that the cleanliness in their residential hall and cafe are in good condition. $60.5 \%$ of the respondents also agree that the cleanliness in their school and faculty is good. Moreover, most of the respondents also agree that the cleanliness in the public buses and most of the public places in their university is in good condition. Based on the results, we could see that cleanliness is the priority by all parties.

Table 3. Surroundings Information

\begin{tabular}{|c|c|c|c|}
\hline Questions & Group & Total & Percentage $(\%)$ \\
\hline $\begin{array}{l}\text { How do you feel the cleanliness in } \\
\text { your student residential hall? }\end{array}$ & $\begin{array}{l}\text { Very Good } \\
\text { Good } \\
\text { Neutral } \\
\text { Poor } \\
\text { Very Poor }\end{array}$ & $\begin{array}{l}12 \\
95 \\
67 \\
25 \\
1\end{array}$ & $\begin{array}{l}6 \\
47.5 \\
33.5 \\
12.5 \\
0.5\end{array}$ \\
\hline $\begin{array}{l}\text { How do you feel the cleanliness in } \\
\text { your student residential cafe? }\end{array}$ & $\begin{array}{l}\text { Very Good } \\
\text { Good } \\
\text { Neutral } \\
\text { Poor } \\
\text { Very Poor }\end{array}$ & $\begin{array}{l}20 \\
88 \\
74 \\
17 \\
1\end{array}$ & $\begin{array}{l}10 \\
44 \\
37 \\
8.5 \\
0.5\end{array}$ \\
\hline $\begin{array}{l}\text { How do you feel the cleanliness in } \\
\text { your school/faculty? }\end{array}$ & $\begin{array}{l}\text { Very Good } \\
\text { Good } \\
\text { Neutral } \\
\text { Poor } \\
\text { Very Poor }\end{array}$ & $\begin{array}{l}30 \\
121 \\
41 \\
7 \\
1\end{array}$ & $\begin{array}{l}15 \\
60.5 \\
20.5 \\
3.5 \\
0.5\end{array}$ \\
\hline
\end{tabular}




$\begin{array}{llll} & \text { Very Good } & 29 & 14.5 \\ & \text { Good } & 89 & 44.5 \\ \text { How do you feel the cleanliness of } & \text { Neutral } & 74 & 37 \\ \text { public buses? } & \text { Poor } & 6 & 3 \\ & \text { Very Poor } & 2 & 1\end{array}$

\begin{tabular}{llll}
\hline & Very Good & 44 & 22 \\
How do you feel the cleanliness of & Good & 101 & 50.5 \\
public places in your place? (Li- & Neutral & 48 & 24 \\
brary, Sport Centre, etc..) & Poor & 6 & 3 \\
& Very Poor & 1 & 0.5 \\
\hline
\end{tabular}

\subsection{Self-Knowledge Information}

Based on the Self-Knowledge Information Survey, that the findings indicate that the respondents are aware of the disease. In general, most respondents have a good Self-Knowledge Information. Table 4 shows that $44.5 \%$ of the respondents strongly agree that dirty hands can transmit the virus. Furthermore, 39.5\% of the respondents agree that proper hand hygiene could prevent someone from getting infected. Meanwhile 55.5\% of the respondents agree that washing hand is necessary, and $40.5 \%$ of the respondents agree that by using face mask could prevent someone from getting infected.

Table 4. Self-Knowledge Information

\begin{tabular}{|c|c|c|c|}
\hline Question & Group & Total & Percentage (\%) \\
\hline $\begin{array}{l}\text { Do you agree that illnesses can be } \\
\text { transmitted by dirty hands? }\end{array}$ & $\begin{array}{l}\text { Strongly Agree } \\
\text { Agree } \\
\text { Neutral } \\
\text { Disagree } \\
\text { Strongly Disagree }\end{array}$ & $\begin{array}{l}89 \\
83 \\
19 \\
3 \\
6\end{array}$ & $\begin{array}{l}44.5 \\
41.5 \\
9.5 \\
1.5 \\
3\end{array}$ \\
\hline $\begin{array}{l}\text { Do you agree that proper hand hy- } \\
\text { giene could prevent someone from } \\
\text { getting infected? }\end{array}$ & $\begin{array}{l}\text { Strongly Agree } \\
\text { Agree } \\
\text { Neutral } \\
\text { Disagree } \\
\text { Strongly Disagree }\end{array}$ & $\begin{array}{l}91 \\
79 \\
23 \\
2 \\
5\end{array}$ & $\begin{array}{l}45.5 \\
39.5 \\
11.5 \\
1 \\
2.5\end{array}$ \\
\hline $\begin{array}{l}\text { Do you agree that washing hand is } \\
\text { necessary? }\end{array}$ & $\begin{array}{l}\text { Strongly Agree } \\
\text { Agree } \\
\text { Neutral } \\
\text { Disagree } \\
\text { Strongly Disagree }\end{array}$ & $\begin{array}{l}111 \\
69 \\
14 \\
0 \\
6 \\
\end{array}$ & $\begin{array}{l}55.5 \\
34.5 \\
7 \\
0 \\
3 \\
\end{array}$ \\
\hline $\begin{array}{l}\text { Do you agree that by using face } \\
\text { mask could prevent someone from } \\
\text { getting infected? }\end{array}$ & $\begin{array}{l}\text { Strongly Agree } \\
\text { Agree } \\
\text { Neutral } \\
\text { Disagree } \\
\text { Strongly Disagree }\end{array}$ & $\begin{array}{l}87 \\
81 \\
26 \\
3 \\
3\end{array}$ & $\begin{array}{l}43.5 \\
40.5 \\
13 \\
1.5 \\
1.5\end{array}$ \\
\hline
\end{tabular}

\section{Discussion and Conclusion}

Based on the study, that the findings of the survey posit that most of the respondents have good self-hygiene as they conduct proper self-hygiene during the pandemic of COVID-19. The findings from 200 students of the 
university that participated in the study show that $63.5 \%$ of the respondents have hand sanitizer when they are in the university, $30 \%$ of the respondents often bring hand sanitizer wherever they go within the university, $48 \%$ often use the hand sanitizer every time they interact with anything, $82 \%$ of the respondents use soap every day in their daily life and they often use soap provided in many public places within the university, after coming back to their student residential hall and before meals in any cafe in the university. The findings also posit that $99 \%$ of the respondents wash their hands after using the washrooms. Moreover, $43 \%$ always wash their hands after using public transport within the university, $30.5 \%$ after having contact with a person and $82.5 \%$ after having contact with animals. Besides, $74 \%$ have a face mask, $36.5 \%$ use it within the university compound, and $87 \%$ of the respondents use face mask when they are out of the university.

Thus, the findings illustrate that the students are aware of the disease. Based on the self-knowledge information survey, most of the respondents have good self- knowledge. The findings of the survey also indicate that $44.5 \%$ of the respondents strongly agree that illnesses can be transmitted by dirty hands, 39.5\% agree that proper hand hygiene could prevent someone from getting infected, $55.5 \%$ strongly agree that washing hand is necessary and $40.5 \%$ agree that using face mask could prevent someone from getting infected.

However, there is still room for the university students to improve their hygiene awareness, by having better awareness and exercising more complete precautionary matters to prevent the spread of COVID-19 as there are continuing efforts to find a vaccine, but even the most ambitious timeline indicate several months of scientific development before the start of human clinical trials. Without a vaccine or treatment, the most effective way to stop the spread of COVID-19 is to restrict transmission by detecting infected individuals as quickly as possible and isolating them for treatment before they can infect others. The strategy was found to be effective against the 2003 outbreak of SARS (Severe Acute Respiratory Syndrome). The methods used during the SARS crisis are being introduced by global and national health authorities, but other steps must also be taken as COVID-19 is already prevalent and spreading super-fast around the world.

In conclusion, based on the findings, the study recommends that students in universities should continue practicing good personal hygiene by maintaining hygiene awareness in order to reduce the spreading of COVID19.

\section{References}

1. Adhikari, S., Meng, S., Wu, Y. et al.: Epidemiology, causes, clinical manifestation and diagnosis, prevention and control of coronavirus disease (COVID-19) during the early outbreak period: a scoping review. Infect Dis Poverty 9, 29 (2020).

2. Agarwal, V., Gupta, L., Davalbhakta, S., Misra, D., Agarwal, V., Goel, A. (2020). Undergraduate medical students in India are underprepared to be the young-taskforce against Covid-19 amid prevalent fears. doi:10.1101/2020.04.11.20061333.

3. Chen, X., Ran, L., Liu, Q., Hu, Q., Du, X., \&amp; Tan, X. (2020). Hand Hygiene, Mask-Wearing Behaviors and Its Associated Factors during the COVID-19 Epidemic: A Cross-Sectional Study among Primary School Students in Wuhan, China. International Journal of Environmental Research and Public Health, 17(8), 2893. doi:10.3390/ijerph17082893.

4. Dalton, C. B., Corbett, S. J., \&amp; Katelaris, A. L. (2020). COVID - 19: Implementing sustainable low cost physical distancing and enhanced hygiene. Medical Journal of Australia, 212(10), 443. doi:10.5694/mja2.50602.

5. Hellewell, J., Abbott, S., Gimma, A., Bosse, N. I., Jarvis, C. I., Russell, T. W., . . Eggo, R. M. (2020). Feasibility of controlling 2019-nCoV outbreaks by isolation of cases and contacts. doi:10.1101/2020.02.08.20021162.

6. LiveScience, https://www.livescience.com/are-face-masks-effective-reducing-coronavirusspread.html, last accessed 2020/06/03.

7. Middle East respiratory syndrome coronavirus (MERS-CoV) - Malaysia. Geneva. World Health Organization, W. (2018).

8. Mohammadi, M., Dalvandi, A., \&amp; Chakeri, A. (2020). A study of handwashing training effects on awareness, attitude, and handwashing skills of third grade elementary school students. Journal of Family Medicine and Primary Care, 9(2), 1149. doi:10.4103/jfmpc.jfmpc_948_19.

9. Novel Coronavirus(2019-nCoV) Situation Report. Geneva. World Health Organization, W. (2020).

10. Or, P. P.-L., Wong, B. Y.-M., \& Chung, J. W.-Y. (2020). To investigate the association between the health literacy and hand hygiene practices of the older adults to help them fight against infectious diseases in Hong Kong. American Journal of Infection Control. 
11. Sarfaraz, S., Rizwan, H., Siddique, S., Firdous, K., Khan, S.: Awareness Regarding Hand Hygiene: A Survey Based Study. American Journal of Pharmacology and Pharmacotherapeutics (2015).

12. What Is Coronavirus? Ways to Prevent - Know the Real World With a Trusted Source: Know Quickly. 27 Jan. 2020, knowquickly.com/what-is-coronavirus-ways-to-prevent/ , last accessed 2020/06/01.

13. World Health Organization, https://www.who.int/malaysia/emergencies/coronavirus-disease(covid-19)-in-malaysia, last accessed 2020/06/12.

14. World Health Organization, https://www.who.int/health-topics/coronavirus\#tab=tab_1, last accessed 2020/06/03.

15. Xiao, J., Shiu, E. Y., Gao, H., Wong, J. Y., Fong, M. W., Ryu, S., Cowling, B. J. (2020). Nonpharmaceutical Measures for Pandemic Influenza in Nonhealthcare Settings-Personal Protective and Environmental Measures. Emerging Infectious Diseases, 26(5), 967-975. doi:10.3201/eid2605.190994. 